ARTICLE

DOI: $10.1057 /$ palcomms.2017.28

\title{
Beyond Hammer: the first run market and the prestige horror film in the early 1960s
}

Mark Jancovich ${ }^{1}$

\begin{abstract}
Although 1960s horror was supposedly dominated by Hammer, Heffernan has pointed out that Hammer (and AIP) were both trying hard to break out of the low bracket market and into the middle bracket. This article focuses on the prestige horror films of the early 1960s, and not only looks at them as a coherent production trend (rather than as a series of individual or anomalous films) but in the process, offers a new context for an understanding of 1960s horror; that is, it demonstrates that the 1960s horror film was not simply low budget cinema but that it operated in almost all the key American film marketsthe first run cinema, the low budget and the art cinema. Consequently, we cannot only see that Hammer and AIP, rather than simply the dominant form, were actually defined by their attempt to steer a course between different sectors of the market (they were from the low budget end but trying to move into the first run market, whilst also drawing on some of the distinction associated with the art cinema); but also that the prestige horror films had their own very specific problems to negotiate. These negotiations would also lay the foundations for the industry-wide transformations of the late 1960s. This article is published as part of a collection on gothic and horror.
\end{abstract}

\footnotetext{
${ }^{1}$ Art, Media and American Studies, University of East Anglia, Norwich, UK Correspondence: (e-mail: m.jancovich@uea.ac.uk)
} 
$\mathrm{n}$ histories of the horror film, the 1960s is usually presented as a crucial period and one that is defined either by the phenomenal success of Hammer's Curse of Frankenstein (1957) or by the making of Psycho (1960). In both accounts, the period is a break from the past and one that witnesses the emergence of the contemporary horror film (Hardy, 1985; Wood, 1986; Tudor, 1989; Worland, 2014). Furthermore, these accounts tend to replicate an image of horror as a low budget, disreputable genre that deals with dark, disturbing and potentially subversive materials, an image that ignores or marginalizes other developments in the period. The result even misrepresents both Hammer's output and Hitchcock's Psycho, neither of which were simply low budget efforts. On the contrary, while Hitchcock was a prestige director who was working on a lower budget than usual, Psycho was in no way a low budget horror film': ${ }^{1}$ and, as Heffernan has demonstrated, even Hammer's horror films were not low budget projects but the product of an explicit strategy by the studio, which was attempting to break out of low budget filmmaking and into the lucrative first run market in the US (Heffernan, 2004). ${ }^{2}$

By the mid 1950s, the major Hollywood studios saw the film audience as one that was divided into four distinct markets, the most valuable of which was the market for huge road show productions (Lev, 2003: 214-215). The first run market was the next most valuable and it was here that, before the 1950s, the major studios had earned $75 \%$ of their profits at a small number of metropolitan picture palaces where they could charge high prices from the affluent middle classes (Gomery, 1986, 1992). The next two markets were seen as more economically marginal so that the major studios had traditionally ignored them or seen them as peripheral to their core business: cinemas catering to working class and small town audiences on the one hand, and the art house on the other, although the latter became increasingly significant throughout the 1960s.

If companies such as Hammer had traditionally been locked out of the profitable first run market, this situation changed in the mid 1950s. On the one hand, the major studios had been forced to sell off their theatres after the Paramount decision of 1948 and no longer had an incentive to provide a yearly schedule for exhibitors. On the other, the studios became increasingly focused on the road show productions during the 1950s and early 1960s. These two factors encouraged the major studios to lose interest in the production of regular programming, a situation that caused a crisis for exhibitors who welcomed the intervention by companies such as Hammer, which filled the gap left by the majors (Lev, 2003; and Alpert and Beaumont, 1959). Hammer therefore needs to be seen as a studio that, between 1957 and the late 1960s, was defined by its strategy for the first run market, and by its position between the low budget producers on the one hand and the major studios on the other. ${ }^{3}$ However, if the British studio had a largely free hand between 1957 and 1960, the success of Hammer and other smaller producers inspired the prestige producers to develop horror films of their own, productions that were often budgeted well beyond the means of companies such as Hammer.

The following article will therefore explore this cycle of prestige horror films targeted at the first run market, most of which followed a series of basic strategies. For example, the female market had long been seen as key to the first run market, and it was therefore hardly surprising that many of the prestige horror films were directly targeted at female audiences, and featured female stars with strong associations with the woman's film. Furthermore, in the 1940s, the woman's film and the prestige horror film may not have been synonymous with one another but there had been a substantial amount of overlap between the two, with the most requested re-release of the 1940s being Rebecca, a clear example of a woman's film that was also a prestige horror film, and one that was heavily imitated throughout the decade (Jancovich, 2014). As a result, during this earlier period, many of the key horror films were female-centered and many of the key examples of the woman's film were generically marked as horror films.

In the 1960s, then, many of the prestige films returned to this model (and often explicitly evoked memories of these earlier films) while also employing two other strategies. On the one hand, many of the prestige horror films were adaptations of literary and/or theatrical properties, a tendency that was not simply an attempt to exploit presold materials but also to evoke the quality of more legitimate art forms. The second strategy was a strong preference for "psychological" horror along the lines of the prestige horror films of the 1940s, and this strategy not only included examples of the Gothic (or paranoid) woman's film, in which the female lead was driven to the point of psychological breakdown by her tormentors, but also a fascination with the figure of the psychologically disturbed villain (often a serial killer) whose presence clearly predated Psycho and was also a key feature of the prestige horror films of the 1940s. There was also a corresponding avoidance of supernatural materials, with the exception of stories involving ghosts and/or witchcraft, both of which could be given a psychological spin that stressed "suggestion" rather than "explicitness" and allowed the possibility of a rational, rather than a supernatural, explanation for mysterious and uncanny events.

The account that follows, however, is based three different types of reception materials: marketing materials, particularly trailers, and reviews in Variety and the New York Times. Certainly, there are a range of other sources, such as production files and the documents of the Production Code Administration, that would have provided valuable insights, too, and Heffernan's work here has been invaluable (Heffernan, 2004). However, the constraints of word length and the desire to maintain a conceptual focus have necessitated considerable restraint in the selection of materials. The production process is certainly worth understanding but it does not give us access to how films were likely to be consumed, just as the ways in which films are consumed does not provide an understanding of the contexts within which they were made. Consequently, the focus here is on reception materials rather than production records, in much the same way that most studies of production focus on production documents rather than reception materials. Indeed, even the selection of reception materials also requires further restraint, given the richness and the variety of these sources. There is an astonishing range of reception materials that one could study but the aim of this account is not to provide an (impossibly) comprehensive account of all of the ways in which prestige horror films were discussed within the period but rather to examine some key structures and distinctions that were in operation at the time.

The selection of these three sources has therefore been strategic, with all three providing clear and distinct senses of how the market for the prestige horror films was imagined and how individual films were seen as appealing to this market. Trailers, for example, made the most direct address to audiences and offer a sense of the ways in which individual films were supposed to appeal to these markets. The point is not whether the audiences were convinced by this marketing but rather to clarify the terms within which these films were supposed to appeal to their potential consumers. Alternatively, the reviews in Variety were not aimed directly at these audiences but rather at exhibitors; and these reviews were designed to offer exhibitors advice about the likely audiences for individual films, and hence whether exhibitors should book these films and, if they did so, how to promote them. Finally, the reviews in the New York Times 
were not aimed at the exhibitors, nor was it simply concerned with selling films to audiences. If these reviews provided some advice to audiences about whether or not to see a particular film, the critics associated with this publication were far more concerned to provide a broader sense of commentary on individual films and their relation to film culture in general. In other words, the New York Times was highly concerned with its role as a "tastemaker": it offered more than consumer advice and saw its role as being to defend and even advance the aesthetic standards by which films were judged. As Beaver has argued, the newspaper's screen editor and foremost film critic at the time, Bosley Crowther, wanted reviews that went beyond "simply reflecting public taste", and sought to convince "the public of the motion picture's artistic and social potential" (Beaver, 1974: 16). Furthermore, as a critic of immense importance and influence in the period, Crowther may not have represented avant-garde tastes but he did represent legitimate taste. Certainly, there were publications that might have better reflected the "run of the mill" first run audience member (if such a thing ever existed), but the importance of the New York Times was that it represented what was generally acknowledged to be "right", even by people who did not share those tastes.

In other words, while these three materials are not identical and give different perspectives, and while both the New York Times and Variety featured a number of different reviewers, reviewers who inevitably had different personal preferences, the point here is to focus on the structuring oppositions in relation to which judgements were made. On the one hand, despite the difference between reviewers, both publications maintained a clear editorial policy that defined the terms within which individual reviewers operated and, on the other, the question is not whether a review in the New York Times praised, or condemned, a particular film; but rather the ways in which these judgements were defined in terms of a pre-established structure of distinctions. Different publications, and/or the individual critics who wrote for these publications, may have debated where a specific text stood in relation to specific categories but the distinctions between categories were still in operation.

Furthermore, the above claim about the categories of taste also applies to categories of genre. In other words, the article does not set out from a predetermined definition of horror as a genre, but seeks to examine how generic categories were defined within the late 1950s and early 1960s. Genre categories are not simply defined by some "Factor X" which remains fixed across time. On the contrary, generic categories are historically specific so that understandings of genre in one period cannot be simply applied retrospectively onto earlier periods; and while some readers may be surprised at the films that are discussed here, and even object that certain films are not really horror films, the article makes its selection on the basis the ways in which critics in the 1960 s generically categorized specific films and understood larger generic categories. ${ }^{4}$ In this context, the wideness with which the net has been cast, and the seemingly eclectic range of texts that has brought together as a result, is crucial; the article seeks to select films on the basis of the ways in which they were generically understood at the time and, in the process, to move beyond the texts that are commonly discussed as horror today; or rather to provide a new sense of the landscape of horror in the period, a landscape that then requires us to see the familiar landmarks within a new context.

However, given that, as Rick Altman has pointed out, films are rarely explicitly marked generically but rather though terms that "imply generic affiliation" without stating it (Altman, 1999: 128), the following article will look at these trailers and reviews in a number of ways. It will explore the terms through which "generic affiliation" is implied, and target audiences are indicated.
Furthermore, it will examine the distinctions in relation to which judgements of quality were made, and the various factors that were associated with these judgements of quality. It will also provide a largely narrative account of the development of this cycle from the late 1950s, when the studios began to respond to the success of companies such as Hammer, and until the mid 1960s, when the situation began to change and the studios started to abandon the road show strategy and refocus their attention on the first run market, a period which also saw the majors appropriate the strategy of companies such as Hammer who had simultaneously sought to target youth audiences while also exploiting the appeal of art house cinema.

The first section therefore focuses on the initial prestige horror productions which either aspired to be serious and important films through their use of adult content or, conversely, were targeted at the family audience through their more "juvenile" appeal. The second section then moves on examine the ways in which some films, such as Psycho, explicitly tried to copy aspects of the low budget horror films but also clearly marked themselves out as more quality productions; while others, such as Midnight Lace (1960), explicitly employed a glossy and glamorous look in an explicit appeal to female audiences. The next section then focuses on the tension between seriousness and sensationalism, and the ways in which the supposedly shocking realism that was used to suggest seriousness was often seen as indistinguishable from low brow sensationalism; while the attempt to avoid sensationalism was often criticized for failing to deliver the pleasures expected of an effective horror film. This section also demonstrates the ways in which the aesthetics of camp became a key feature of horror during the period and one that frustrated, or complicated, the opposition between seriousness and sensationalism. These issues also raise the specter of the art cinema and the next section looks at the ways in which a number of horrific art films managed to achieve success with first run audiences while elsewhere the horror film was become more glossy, glamorous and drew on some of the most prestigious talent in Hollywood. Finally, then, the article considers the tension between realism and restraint in the horror films of the mid 1960s. In other words, by the mid 1960s, the serious, realistic handling of materials was increasingly seen to conflict with the respectability and restraint previously expected in the first run market and, in this context, Polanski's Repulsion (1965) came to represent a new type of horror cinema which drew on the art cinema and challenged the timidity of Hollywood conventions. Furthermore, it did so at a time when the major studios were about to move away from the road show strategy; to target new markets (particularly the youth market); and to reject the systems of self-censorship that had previously guaranteed the respectability of Hollywood films to affluent middle class audiences, a system that had come to be seen as limiting and outmoded by many in the mid-1960s (Monaco, 2003).

\section{Adult films and family movies: forging first run horror}

The first major contribution to the prestige horror films came in 1959, Compulsion, a film that drew on the famous Leopold-Loeb case that had also been fictionalized by the novelist and playwright Patrick Hamilton (Angel Street/Gaslight, Hangover Square and Rope, all of which were adapted for the screen as contributions to the prestige horror cycle of the 1940s). However, Compulsion did not return to Hamilton's treatment but was based on a "documentary novel" (Weiler, 1959: 26) that trailers described as a "sensational bestseller" and one that had already been adapted into a play that had "shocked Broadway". The film's status as a prestige production can also be seen in its budget (US $\$ 1.5$ million) and its director, Richard Fleischer, who had 
previously directed the phenomenally expensive and commercially successful, 20000 Leagues Under the Sea (1954), and Kirk Douglas's lavish historical epic, The Vikings (1958). Indeed, Fleischer would return to the prestige horror film again and again throughout the 1960s and early 1970s, during which he directed Fantastic Voyage (1966), The Boston Strangler (1968), 10 Rillington Place (1971), Blind Terror (1971), and Soylent Green (1973). Furthermore, he made these horror films alongside a series of huge, prestige (and often road show) productions such as Barabbas (1961), Doctor Doolittle (1967) and Tora! Tora! Tora! (1970).

Compulsion also asserted its prestige through stars such as Orson Welles, who not only contributed "the finest portrayal to this searching drama" (Weiler, 1959: 26) but had also been a key figure in the prestige horror film of the 1940s (Jancovich, 2009). The relationship to Hamilton's fictionalization of the LeopoldLoeb case, Rope, also associated the film with Hitchcock who had adapted Hamilton's play for the big screen in 1948 and was another key director of the prestige horror films of the 1940s (Jancovich, 2011). Finally, then, Compulsion was praised for the ways in which it "dramatically probes the characters of its principles" (Weiler, 1959: 26), characters whose "abnormal psychology" marks the film as clear example of the psychological horror film.

However, although the film was predicted to do well with first run audiences, reviewers were divided over the film. On the one hand, the film's status as a prestige picture was emphasized through the supposedly serious, uncompromising realism with which it handled its materials. Consequently, the film was described as "frank" (Hift, 1959: 6), probing and "documentarylike" (Weiler, 1959: 26). On the other hand, this realism was in tension with other claims about the film and, while the New York Times praised the film as one that was "never blatant" and "made a dark deed into a bright and fascinating picture" (Weiler, 1959: 26), Variety claimed that the film's refusal to be "blatant" contradicted its claims to "documentary-like" realism and made the film too restrained: it has an "almost sober atmosphere" in which the "terror of [the events] never fully penetrate" (Hift, 1959: 6).

If Compulsion was an attempt to make a prestige horror film for the first run market, two other first run productions took a very different course and, rather than target the audience for serious, adult drama, these films were designed for the family audience. Journey to the Centre of the Earth (1959) was seen as recycling elements of 20000 Leagues Under the Sea (1954), and as being a "science fiction" adventure with some horror elements. For example, trailers for the film made much of its "monstrous flesh eating" creatures, creatures which the New York Times claimed were unlikely to "frighten" anyone except "little children" and dismissed the film as a "lurid adventure" that lacked "plausibility" (Crowther, 1959b: 51). The film was therefore read as a piece of family entertainment with "appeal mainly to the young" by which it meant the pre-teen audience, but it was also claimed that the film features "a built-in teenage attraction in the person of Pat Boone", although it was emphasized that he "draws the non-delinquent element of the juve trade." (Holl, 1959: 6) Even adults were told that they could get pleasure from the film, on the condition that they shared its "tongue in cheek approach" and treated it as a "spoof" (Holl, 1959: 6).

Alternatively, On the Beach (1959) was seen as anything but a "spoof" and marketing for the film claimed that, with its release, "motion picture history is made". In part, its status as a historic event was supposedly because of the "first world wide premiere" that was used to launch the film, and in which the film's stars were sent out as ambassadors to premieres across the globe, premieres that also featured major political figures. This "world wide premiere" was a way of trumpeting the film's supposed significance as a statement on nuclear issues, a significance that was also emphasized through references to its producer, Stanley Kramer, references that stress the number of serious issue pictures that he had made.

If marketing presented the film as one of high moral seriousness, reviews of the film did not challenge this view but rather described it as a "deeply moving picture" (Crowther, 1959c: 34) that was "honest and provoking" (Powe, 1959: 6). Certainly, its topic the aftermath of nuclear war was claimed to be "grim" but the fact that it was also one that was common to low budget horror films throughout the 1950s was carefully avoided by reviews, which did not associate the film with this exploitation tradition or even imply any generic affiliation at all. Indeed, reviews emphatically presented the film as a serious and life affirming one, a film that stressed that "man is worth saving after all" (Crowther, 1959c: 34) and that was "something to be seen" because of the importance of its subject matter (Powe, 1959: 6).

If Journey to the Centre of the Earth continued a tradition of period science fiction films that had started with 20000 Leagues Under the Sea, the tradition continued into 1960 with two examples, both of which ramped up the horror elements, George Pal's The Time Machine (1960) and Irwin Allen's The Lost World (1960). The Time Machine was marketed as an adaptation of a literary classic by H.G. Wells, and the film was claimed to feature "fiendish creatures" and "cannibalistic horror" and, while critics tended to describe the film as "science fiction", they also noted: "There is wholesale horror in these passages of the film, highly exploitable shock material and a particularly vivid but not overly frightening experience for children" so that the film was one that should appeal to the family audience (Tube, 1960b: 6).

In much the same way, The Lost World was marketed with a heavy emphasis on its monsters but, in this case, reviewers claimed that its actors, script and direction "are no competition for the prehistoric monsters", which were clearly seen as the film's main attraction, a judgment which was hardly complimentary (Tube, 1960a: 6). If Journey to the Centre of the Earth and The Time Machine were seen as films that would appeal to the whole family, even if adults had to treat the former film as a "spoof", The Lost World was seen as unfit for "moviegoers past voting age" (Weiler, 1960: 23).

\section{Economy, extravagance and prestige in the early 1960s}

If 1959 had seen the first forays into prestige horror production, the first two years of the next decade can be seen as a period of transition or adjustment, in which various options were explored and after which there was a continued and steady increase in production. Most significantly, 1960 saw two divergent approaches with Hitchcock's Psycho representing one alternative and Ross Hunter's Midnight Lace representing an opposite strategy but one that would prove (perhaps counter to expectations today) highly influential. Nor was Hitchcock alone in his approach and, at the same moment, Michael Powell engaged in a similar experiment, ${ }^{5}$ although with a quite different response. Both directors chose to ditch the budgets to which they had been accustomed up to that point and made horror films with modest, if not really low, budgets and production values. The feel of both Hitchcock's Psycho and Powell's Peeping Tom (1960) was therefore far closer to that of the low budget horror films (or art cinema horror films such as Les Diaboliques, 1955) and both films were clearly designed to attract the market for low budget and/or the art cinema horror, although both Psycho and Peeping Tom also exploited the respectability of their directors. Hitchcock even employed the kind of gimmick for which William Castle had built a reputation, so that Psycho was shown in separate performances 
and customers were refused admission after the film had started, a strategy that may have been a gimmick but was also, as Joan Hawkins has noted, an established practice in the art cinema. (Hawkins, 2002)

Elsewhere, I have provided a lengthy account of the various precursors to Psycho, which argues that the film was not the decisive break often assumed by Wood and his followers (Wood, 1986; Jancovich, 1996). For example, Hitchcock had already shown an interest in exploiting the success of the art house horror hit, Les Diaboliques, in Vertigo (1958): both Clouzot's film and Vertigo were based on books by the same co-authors, Pierre Boileau and Thomas Narcejac. However, Vertigo had still featured the glossy glamorous style of many of Hitchcock's thrillers of the 1950s, and it was precisely this aspect that Hitchcock dispensed with in Psycho. Also, while Psycho was another adaptation, its source novel did not have the respectability of many other prestige horror films. Robert Bloch may have been a well-known and respected writer in genre circles but he had hardly broken out of genre fiction and attained respectability beyond it.

None the less, Psycho was also clearly marketed on Hitchcock's well known persona, particularly as the host of the television series, Alfred Hitchcock Presents (1955-1962), which its trailers evoked in style, even using the theme music from the series. In other words, trailers featured the director addressing the camera directly and insinuated all sorts of morbid details: he not only talks of "dire, horrible events", and describes Norman's mother as "the weirdest", but he also stresses the gorier elements of the story: "You should have seen the blood!" However, while proudly declaring the film to be "Alfred Hitchcock's Greatest Shocker", the emphasis was, as with the television show, on the shocker as a fun, almost a kind of practical joke. In this way, these trailers did not present the film as a departure for the director. On the contrary, rather than a break from his previous films, horror was not only seen as his natural habitat but one in which he was the master. It may have been the director's "Greatest Shocker" but this implies that he was known for his shockers, an implication that, at least in part, worked to evoke memories of the Hitchcock of the 1940s, when he had been the preeminent director of prestige horror films.

A similar sense was also present in reviews of the film, which claimed that the director was "an old hand at frightening people", even if it was claimed that, in Psycho, he "comes at you with a club" (Crowther, 1960a: 37). It was not a surprise that Psycho was a "frankly intended blood curdler": the surprise was that the film lacked "subtlety". However, while the film employed "old fashioned melodramatics" that might remind one of the low budget shockers, it was also carefully distinguished as a prestige production through the presence of stars such as Janet Leigh, John Gavin and Vera Miles, stars more usually associated with big budget, glossy productions. In other words, these stars were insurance: reassuring markers of quality that distinguished the film from the productions of Castle and others, even while $P$ sycho's style and themes sought to attract the youth audience associated with the low budget films.

This use of stars was particularly important given that another key strategy for distinguishing the prestige films was difficult for Psycho. If many prestige horror films used psychological horror as a way of asserting their quality, Psycho was not marketed as a serious psychological study along the lines of Compulsion. Consequently, although it was clearly a psychological horror film, reviewers were skeptical about this aspect of the film; and both the New York Times and Variety cast doubt on the film's accuracy as a psychological study. Variety even warned viewers that the supposedly "Freudian motivations" of the film's characters should "not be taken too seriously" (Gene, 1960: 6); while the New York Times suggested that the director's "points of psychology" were not "as reliable as his melodramatic stunts", and might even be "a bit of leg pulling from a man who has been known to resort to such tactics in his former films." (Crowther, 1960a: 37) The film was therefore, as Kapsis (1992) has argued, carefully constructed to achieve a commercial success with teenage audiences, and with first run markets, while also seeking to elicit the critical and art house cachet that Hitchcock coveted; and if it failed to achieve the critical adoration that the director so desired, it did prove a phenomenal hit that transformed his career thereafter.

The same fate was not enjoyed by Powell, whose Peeping Tom followed a similar strategy to Psycho (he made the film on a much smaller budget than he was used to) but proved neither critically nor commercially successful, a situation that virtually destroyed the director's career. Again, as has been demonstrated elsewhere, Powell had been strongly associated with the 1940s horror cycle (Jancovich, 2012b); and Peeping Tom was another a psychological story about a deranged serial killer. One trailer for the film therefore referred to the film's killer as a "madman", and as a man driven by a "compulsion akin to madness". Similarly, Variety claimed that the film was a "chilling yarn about a psychopathic killer." (Rich, 1960b: 8) Marketing for the film also sought to demonstrate the quality of the film through references to its director, and his previous films, particularly his highly praised fantasy projects from the 1940s. However, unlike Psycho, Powell's film was not an adaptation and the cast were not stars or even actors with whom first run audiences would have been familiar.

Consequently, there was some doubt over the quality of this picture, and the New York Times does not seem to have even reviewed the film. Variety on the other hand claimed that its "muddled script" and "plot ... would have emerged as a shoddy yarn", had it not been "saved from unpleasantness by shrewd direction", which lifted the film "above level of a run of the mill horror film" (Rich, 1960b: 8). In other words, Powell was seen as raising the level of "shoddy" materials rather than as transforming them into something of quality and, while Hitchcock's horrors could be forgiven as playful "leg pulling", Peeping Tom was seen as a dark and sordid tale that was not lightened with humour.

A slightly different strategy was behind Village of the Damned (1960), which was an adaptation of John Wyndham's novel, The Midwich Cuckoos, Wyndham being one of the few science fiction writers to have broken out of the genre and achieved mainstream recognition by the late 1950s. It also featured familiar Hollywood stars, particularly George Sanders, who had been a key figure in the 1940s, when he had been heavily associated with the prestige horror film (Rebecca [1940], Foreign Correspondent [1940], Rage in Heaven [1941] Man Hunt [1941] The Lodger [1944], Hangover Square [1945], The Picture of Dorian Gray [1945] Uncle Harry [1945], and Lured [1947]; see Jancovich, 2015). If Village of the Damned was not a psychological horror film, its identification as "science fiction" asserted an overtly rational (if fantastic) explanation for its storyline, which was nonetheless clearly marketed as a "terrifying" one.

Significantly, MGM had originally planned to shoot the film at its Culver City studios in California but switched the production to the United Kingdom late in the day. Like Psycho and Peeping Tom, then, the film was produced to explicitly evoke aspects of the low budget horror films that had preceded it, even as other aspects sought to distinguish the film from these low budget rivals. The result was an uncertain reception in which Variety dismissed it as a "tired", "strange, sick film" that was only fit "for undiscerning audiences" (Rich, 1960c: 8). But, in complete contrast, many other sections of the press praised the film as a clear departure from earlier low budget horror films, so that the New York Times claimed that it was "a quietly civilized exercise" 
and one that "is one of the trimmest, most original and serenely unnerving little chillers in a long time" (Thompson, 1960: 43).

Sanders also appeared in Bluebeard's Ten Honeymoons (1960), which featured the "mass murderer" of many psychological horror films (Rich, 1960a: 22) and made explicit reference to the Bluebeard legend, many examples of the Gothic (or paranoid) woman's film of the 1940s being explicitly identified as retellings of the Bluebeard story (Jancovich, 2013). But this film had a quite different reception from Village of the Damned, with Variety dismissing it as a "dull, pretentious yarn" that was "unlikely to make the grade even as a dueler" (Rich, 1960a: 22). The accusation of "pretension" is especially significant, given that the film was therefore condemned for being neither one thing nor the other: neither a low budget horror film that knew its place, nor a film of real quality. However, the New York Times went further and objected that the film offered no motivation for its killer's actions and was even claimed to be violation of 1947's Monsieur Verdoux (Archer, 1960: 32), which was Chaplin's own version of the story and his contribution to the 1940s horror cycle, a film that the New York Times had praised at the time and had since been raised to the status of a classic (Jancovich, 2010).

In contrast to these productions, Midnight Lace followed a quite different strategy and one that was to prove far more prescient. If Hitchcock had ditched the glossy and glamorous style of his 1950s thrillers, Midnight Lace was an overtly opulent picture, a feature that the critics were at pains to point out: "Everything in it looks expensive-Rex Harrison, Doris Day, his suits, her clothes, his London Office, their duplex flat in Grosvenors Square" (Crowther, 1960c: 27). Furthermore, its stars were not simply expensive, but also signified prestige of the highest caliber. For example, one trailer identified Harrison as the star of My Fair Lady, a musical for which he won a Tony Award in 1957. Furthermore, Doris Day was not only the star of Midnight Lace but, in both 1959 and 1960, she was listed as one of the top ten moneymakers in the Hollywood film industry.

These features were seen as ensuring that the film should "attract female patrons" (Tube, 1960c: 6), and it was clearly modelled on the Gothic (or paranoid) woman's film of the 1940s. Trailers claimed that "fear possesses" its central character, who finds herself trapped "in a web of silken suspense"; and the film was therefore also seen as a psychological horror film in which the "terrorized Miss Day" is psychologically tormented by a mysterious male figure, who "causes her great mental anguish". Prestige was also implied through its association with the theatre, the film being an adaptation of a play by Janet Green; and, finally, the film's producer was Ross Hunter, a key producer of the 1950s woman's film, who had worked with Sirk and others. However, it was the expense of the film to which many reviewers kept coming back, with Variety commenting on Hunter's "emphasis on visual satisfaction" (Tube, 1960c: 6) and the New York Times describing Midnight Lace as "a multi million dollar thriller" in which the "décor [is] absolutely posh" (Crowther, 1960c: 27).

\section{Seriousness, Sensationalism and camp}

In 1961, another three films related to the emerging cycle of prestige horror films were released, films that illustrated tensions within the critical reception of this cycle. If the prestige horror films often sought to establish their prestige through an assertion of seriousness, this seriousness has two divergent dangers. Certainly seriousness was seen as important by critics but, on one hand, the ways in which some films used shocking realism to suggest a sense of seriousness and prestige was seen by critics as indistinguishable from the sensationalism of the exploitation market; while, on the other hand, the same critics deplored horror films in which aspirations to seriousness worked against their effectiveness as horror productions.

Furthermore, while the opposition between seriousness and sensationalism had long been a structuring one for many critics, it was beginning to be complicated by the aesthetics of camp. As various authors have shown, camp strategies had been a feature of film consumption since the 1930s at the very least (Taylor, 1999; Jancovich, 2010) but the early 1960s was a key moment with a series of art practices being associated with camp, and cultural critic, Susan Sontag, publishing a crucial article on the subject in 1964 (Sontag, 1964). On the one hand, as Klinger has argued, camp rejected the "seriousness" of the avant garde establishment and provided "a gleeful alternative to repressive canons" (Klinger, 1994: 134) but, on the other hand, for this very reason, it was also condemned by many critics for lacking seriousness. Film also had a privileged place in 1960 s camp, given that camp was heavily identified with a gay subcultural aesthetic, and that movie houses had long been key sites of congregation for these subcultures (Suarez, 1996).

Furthermore, as Klinger demonstrates, camp was not simply confined to gay subcultures but was also part of a more general trend that she calls "mass camp":

There are varieties of camp response that are distinctively gay or otherwise subcultural. But there are also forms of camp born of mainstream mass cultural conditions affecting the general population. Since the 1960s, a combination of social and media developments has caused an efflorescence of camp in culture at large, making it a sensibility available to many. This more institutionalized form of camp or mass camp has produced a major set of dynamics influencing how classic Hollywood films ... appear within a contemporary setting. (Klinger, 1994: 133)

This larger sense of camp was the product, for Klinger, of a recycling of films on television and in the revival houses of the 1960s; and it involved a very double edged attitude in which the pastness of classical Hollywood came to be seen as both a nostalgic Golden Age and as hilariously naïve and outmoded.

Horror also had a central role in this process. One of the first film packages to be sold to television featured the Universal horror films of the 1930s and 1940s; and these horror films not only proved popular on television but, by the 1960s, were even inspiring television shows such as The Munsters (1964-1966) The Addam Family (1964-1966). Indeed, as we have already seen, Hitchcock's Psycho was sold through Hitchcock's reputation as a director of Hollywood classics and as the host of the television show, Alfred Hitchcock Presents.

In this way, camp not only caused problems for the traditional opposition between seriousness and sensationalism but provoked strong responses from cultural tastemakers, such as the reviewers associated with the New York Times, for whom camp blurred the lines between the two and thereby threatened, or at least complicated, the distinctions on which its judgments depended. The period therefore saw a series of concerns about the line between the prestige horror film and the materials available on TV but also about a self-conscious and/or histrionic style of horror that was emerging during the period.

The reception of Sanctuary (1961) demonstrates the more familiar concern that shocking realism could become indistinguishable from melodramatic sensationalism; and while it was directed by Tony Richardson, the British "new wave" director, the film was condemned as one in which "realism" ended up as nothing more "melodrama of the most mechanical and meretricious sort" (Crowther, 1961a: 31). Alternatively, while 
Sanctuary was a psychological study of a tormented young woman that was clearly "not a picture for children" (Tube, 1962: 6), another key release of the year, Voyage to the Bottom of the Sea (1961), was science fiction adventure with elements of horror that would only appeal to children. If it was "mildly diverting" (Tube, 1962: 22), it was claimed to lack the virtues of Journey to the Centre of the Earth and The Lost World and, despite its "sleek production", to be "a dramatically unsound sci fi adventure tale" (Weiler, 1960: 23).

However, the key prestige horror film of the year was The Innocents (1961), which was marketed as "a ghost story created especially for the adult moviegoer" and heavily sold on the basis of Deborah Kerr, "one of the world's great stars"; Jack Clayton, "the man who directed Room at the Top"; and even its studio, Twentieth Century Fox, the studio that had made "such outstanding motion pictures immortals as The Snake Pit, Gentleman's Agreement and Peyton Place". The use of these three films in the marketing of The Innocents is of considerable significance, given that all were prestige "issue" pictures, two were examples of the woman's film, and one (The Snake Pit, 1948) was a psychological film that had also been a contribution to the prestige horror films of the 1940s (Jancovich, 2007). Indeed, critics explicitly picked up on the psychological nature of the horror, with Variety describing The Innocents as "an offbeat psychological drama" (Rich, 1961: 6), while the New York Times claimed that it concerned "the creeping terror and [psychological] disintegration of the governess", a "morbid young woman" who "would quickly be labelled psychopathic in this more knowing day." (Crowther, 1961b: 15)

The film was also marketed around other indicators of quality, particularly as an adaptation of a literary classic by Henry James, Turn of the Screw, another adaptation of which had been televised only a couple of years earlier, when it had featured one of the key stars of the 1940s Gothic (or paranoid) woman's film, Ingrid Bergman (Jancovich, 2016). Indeed, The Innocents featured other stars with associations with the prestige horror films of the 1940s. Not only had Deborah Kerr come to stardom through Michael Powell's Black Narcissus, but Michael Redgrave had played the iconic role of the possessed ventriloquist in the celebrated British horror film, Dead of Night (1946), and the psychotic husband in Fritz Lang's Secret Beyond the Door (1947). Indeed, The Innocents worked so hard to establish associations with the past that critics dismissed it as "old fashioned".

Consequently, while Variety praised the film as a "high quality spine chilling drama", that "catches [the] eerie spine chilling mood right from the start and never lets up" (Rich, 1961: 6), the New York Times took a very different line: "Folks who have never seen a movie set in a scary old house, where doors creak and the wind howls around corners, ghosts pace the long, dark halls, and hideous, spectral faces appear at windows, should find themselves beautifully frightened, and even intellectually aroused" (Crowther, 1961b: 15). But ultimately the film was only fit "for folks who haven't seen this sort of thing before" and "old hands long familiar with the traffic and tricks of horror films will feel a bit bored". Interestingly, then, no necessary distinction was made between "the sophisticated viewer" and the horror audience, and it was claimed that "the sophisticated viewer" would not recognize it as "a first rate horror film" exactly because they would be "bored" and regard it as "old fashioned".

By 1962, the production of the prestige horror films began to seriously gain momentum with two tales of contemporary psychological terrorization, Cape Fear (1962) and Experiment in Terror (1962), leading the way. The former was male-centered and built around two key Hollywood stars, Gregory Peck and Robert Mitchum, the latter playing a "psychopath" with a vendetta against the former (Pitt, 1962: 8). If the marketing for the film claimed that it was "the screen's most terrifying war of nerves", and even "the ultimate in shock", critics seem to have largely agreed with this estimation. Variety described the film as a "horror tale" that provided a "forthright exercise in cumulative terror" (Pitt, 1962: 8); while the New York Times described it as "a coldblooded, calculated build up of sadistic menace and shivering dread [that] is accomplished with frightening adroitness", a film for those that "want to be horrified" (Crowther, 1962b: 35), although both Variety and the New York Times explicitly warned that it was "not for kiddies" (Pitt, 1962: 8). However, for all its effectiveness, both the New York Times and Variety objected to the film on moral grounds with the latter declaring the film to be "essentially an amoral entertainment" (Pitt, 1962: 8), while the former claimed "this is really one of those shockers that provokes disgust and regret" (Crowther, 1962b: 35).

If this film was built around its male stars, Experiment in Terror centered on its female protagonist (although she is supported by a policeman played by Glenn Ford). Indeed, Variety made special mention of Lee Remick, for whom the role is "a handsome [one] played with nicely-modulated control and natural feeling" (Dale, 1962: 8). The film not only featured established stars (Glenn Ford) and new talent that was being groomed for stardom (Remick) but it was also directed by a prestige director, Blake Edwards, who may have started out acting in low budget horror films during the 1940s horror cycle but had, by the 1960s, become a director of glossy and glamorous Hollywood productions such as Operation Petticoat (1959) and Breakfast at Tiffany's (1961). Again, the Variety review stressed that the film was an adaptation, and one based on a story in Ladies Home Journal, a source that clearly implies that the film was one targeted at the female audience, despite being a "terrifying" story in which a "psychotic killer" menaces Remick's character (Dale, 1962: 8). The New York Times also saw the film as a "straight exercise in the melodramatic" that was designed to induce "goosepimples" and was loaded with "shock effects"; but while it acknowledged that Edwards had "obviously studied Hitchcock, Huston, Read, et al." (Crowther, 1963a: 31), the review had some complaints. For the New York Times, it was "for those who have not become exhausted with such fare on the television screen", where they "would do it in an hour ... and it would probably be every bit as good". In other words, for all its aspirations to quality, Experiment in Terror suffered the same problem as The Innocents. Their attempts to evoke the past made them look too familiar and old fashioned, while they struggled to distinguish themselves from materials already available on television.

Given that the horror film and the crime thriller are often seen as distinct genres today, and that one might therefore object that Cape Fear and Experiment in Terror are not really horror films, it is important to remember that, during the 1940s, this kind of film was understood as part of the horror genre and that, even in the 1960s, these two films were explicitly associated with horror through their titles and marketing campaigns. The same is also true of The Manchurian Candidate (1962), which the Variety praised as a "first rate offbeat suspense drama" that was likely to be "one of the year's big grosser", despite a situation in which there "has never been anything quite like it" so that it is ultimately "hard to define" (Auby, 1962: 6), a claim around which the marketing campaign was largely organized. The film was also sold as an adaptation of Richard Condon's bestselling novel, and through the reputation of its young director, John Frankenheimer, and its stars: Frank Sinatra, Lawrence Harvey and Angela Lansbury, who had made her name in 1940s prestige horror films such as MGM's lavish productions of Gaslight (1944) and The Picture of Dorian Gray. 
The association with horror, however, was not limited to the presence of Lansbury, so that the New York Times claimed that the film "could serve to scare some viewers half to death", although it qualified this claim: "If they are dupes enough to believe it." (Crowther, 1962c: 48) In other words, the review did not doubt that the filmmakers were aiming to scare their viewers, or that they were technically skilled in pursuit of this aim; but only that the story was a plausible one. Even then, the film's lack of plausibility was not seen as being too much of a problem and it was described as being "as wild a piece of fiction as anything Alfred Hitchcock might present", a phraseology that is ambiguous: it suggests an association with the television show Alfred Hitchcock Presents as much as Hitchcock's cinematic classics. In other words, the New York Times was unconvinced by the film's claims to political satire but praised it as a psychological horror film in which Laurence Harvey's "hypnotized hero" is a "darkly moving evil force" that is psychologically dominated by "Moscow's Frankensteins".

However, the sensational horror hit of 1962, and the most explicit influence on later horror films of the period, was another female-centered psychological drama and one that was seen as taking the Gothic (or paranoid) woman's film to histrionic heights, What Ever happened to Baby Jane? (1962). The marketing for the film focused on its status as horror and claimed that it was a "bold essay in the art of the macabre" that was "not for the squeamish" and featured "shock after shock" so that the film was "a venture to the ultimate reaches of terror". However, the main focus of the marketing was on the film's two female stars, Bette Davis and Joan Crawford, both of whom had strong associations with the 1940s, even if neither had particularly strong associations with the female-centered, horror films of the period, although some of their films that were clearly related to them (A Stolen Life, 1946; Deception, 1946; A Woman's Face (1941); Mildred Pierce (1945); Humoresque (1946); and Possessed (1947)). Nonetheless, What Ever Happened to Baby Jane? did not just allude to the horror films of the 1940s, or even feature two veteran stars from the period, it was explicitly the story of two relics of the classical Hollywood cinema, one of whom even relives her cinematic past through the watching of old television reruns. Furthermore, Variety compared the film with another film about a veteran actress going mad, a film that had been made at the end of the 1940s cycle and had become a classic since: Davis's "slipover into total madness is, possibly, less effective than was Gloria Swanson's in Sunset Boulevard but only because the viewer knows all along that it is unavoidable." (Robe, 1962: 6)

Certainly, What Ever Happened to Baby Jane was clearly identified as a psychological horror film but there was considerable disagreement over its quality, which was partly registered in the general lack of interest in its status as an adaptation. If Variety therefore referred to What Ever Happened to Baby Jane? as the "best shocker since Psycho" and predicted that "word of mouth could make it a top grosser"; the New York Times deplored the film as one of "sheer grotesquerie" (Crowther, 1962d: 48). The film was seen as suitably "blood curdling" and it was conceded that "as a 'chiller' of the old fashioned type - as a straight exercise in studied horror-you may find it a fairly gripping film" but, as this makes clear, the film is ultimately dismissed as both outmoded and an exercise in camp excess.

Consequently, while the film proved a major money maker, and further intensified the horror cycle, the New York Times was far more positive about another film in which horrific materials were treated with seriousness and restraint. Certainly, To Kill a Mockingbird (1962) was not predominantly sold as a horror film, but it was marketed around its horrific elements: "The World never seems as fresh and wonderful, comforting and terrifying, as good and evil, as it does when seen through the eyes of a child". It was also sold through its key star, Gregory Peck, and its status as an adaptation of a book that had won the "Pulitzer Prize and just about every other prize a book can win." If references to "terror" and "evil" in both the marketing and the reviews could be simply be associated with the film's handling of racism, this aspect of the film is also clearly contrasted to the childhood fears that surround "the dark house, where Boo Radley lives" (Crowther, 1963a: 10), and Boo becomes (as his name suggests) a mysterious Bogeyman in the children's imaginations, at least until the two worlds (of childhood fantasy and racist reality) collide and the children are "brought to realize that the strange Boo Radley is not a monster but a friend" (Crowther, 1963a: 10). In other words, the New York Times praised the film highly as one in which the horror materials were handled with a seriousness and restraint that was directly in contrast to the camp excesses of What Ever Happened to Baby Jane?

\section{Art, glamour and the female market}

There was no let up in 1963 but rather an increasingly diverse series of contributions. On one hand, there was a move towards experimentalism, and even a series of key art cinema films that not only had horror elements, but also achieved considerable commercial success. On the other hand, the period saw the production of a number of big budget, glamorous horror films that were explicitly targeted at the female market. The List of Adrian Messenger (1963) was film about a serial killer, and it featured "some well known Hollywood actors got up in disguises" (Crowther, 1963c: 20); a prestige director, John Huston; and was adapted from a novel by Philip MacDonald. However, despite these signifiers of quality, the film was largely dismissed because of the gimmick of disguising its stars, which was supposedly undertaken "at [the] expense of [the film's] story values" (Tube, 1963b: 6). Alternatively, theatre director, Peter Brook, made an adaptation of William Goldman's The Lord of the Flies (1963), which was referred to in one trailer as a "shocking bestselling novel" about schoolboy "castaways degenerating into savagery". Trailers also quoted reviews that claimed that the film was an "expert shocker". If this project lacked stars, it was marketed less as a mainstream commercial production than as an experimental, art house film that would appeal to "connoisseurs of the cinema"; and Variety advised exhibitors that the film would need to be "sold smartly" to achieve its box office potential (Mosk, 1963: 6), and encouraged a focus on the film's horror angles. Similarly, the New York Times described the novel as "stirring and shocking" but complained that Brook had "lost control" of his film so that, for all its pretensions, the intensity of the film's psychological horror was its key strength: "But it is only when the drama reaches the melodramatic point of throwing a large group of youngsters into savage ritualism and ecstasies that the meaning and horror of it come to brief clarity, and the terror of their turning on their old friends is momentarily caught." (Crowther, 1963d: 37)

The Servant (1963) was another art film with horror elements but one that was far more positively received. Certainly, marketing for the film identified the cast as a notable selling point, but as respected actors rather than as stars; but the key emphasis was placed on the film's director, Joseph Losey, and to an even greater extent on its screenwriter, the playwright, Harold Pinter. Before The Servant, Losey already had some associations with horror and had directed a remake of Fritz Lang's $M$ earlier in his career (1951), when he was also making sinister fantasies such as The Boy with Green Hair (1948) and psychological thrillers such as The Prowler (1951). He had also worked with Hammer the previous year on These are the Damned (1962). Similarly, Pinter's plays had already been distinguished by their "menace" 
and "games of domination" (Marwick, 1992). Consequently, trailers identified The Servant as a "sinister" and "shattering" film, but the New York Times went further, describing it as "a flesh creeping demonstration of human destructiveness" and one that is "made all the more horrifying by the genteel surroundings" (Crowther, 1964b: 30). The film was also read as a psychological drama of "patrician degeneration" in which the master falls for the "seductions" of his servant, who exacts a campaign of "emasculation" and "sadism" upon his employer. Consequently, while Variety identified the film as one for the "art circuit", it also claimed that there were "ingredients [that could] make it an offbeat contender" (Myro, 1963: 22), particularly its horrific materials in which the servant, an "evil and menacing character", manages "to dominate his master".

The same year also saw more explicit horror projects such as Hitchcock's The Birds (1963), which was sold as an adaptation of "Du Maurier's thrilling story", Du Maurier being the author of one Hitchcock's most celebrated and commercially successful films, Rebecca, one of the key films of the 1940s horror cycle. The Birds was clearly marketed as a horror film with references to it as a film of "suspense and shock". Hitchcock was even quoted as claiming that it was "the most terrifying picture I have ever made". Indeed, it was Hitchcock, more than his stars, who was sold as the key draw for audiences; and trailers even featured the same comic direct address from Hitchcock that were used to introduce and conclude episodes of Alfred Hitchcock Presents, and to market Psycho. Variety was therefore in no doubt that The Birds was a "shocker", but it complained that the film was "mounted on a rickety story" and was "little more than a shocker for shock's sake." (Tube, 1963a: 6) Furthermore, the problem was not simply that the film lacked the significance expected of a prestige production, but that it was almost "a parody of Hitchcock by Hitchcock". Consequently, while the film diverged from Psycho by returning to the "production gloss" of earlier Hitchcock films, Variety saw the production values as an unsuccessful attempt to suggest quality, and even claimed that the film had a "sci fi exploitation feel" (Tube, 1963a: 6). The New York Times took a similar line. It identified The Birds as a "horror film" but complained that, while the "shock and chills" were effective enough to raise "goose-pimples", the film's significance remained obscure (Crowther, 1963b: 37).

Charade (1963) was another glossy production but not one directed by Hitchcock, although it was clearly modelled on the type of "Hitchcockian" thriller that the director had made in the 1930 s and 1940s, while also replicating the glossy and glamorous look of his 1950s films. It even featured Cary Grant, who had starred in a number of Hitchcock classics: Suspicion (1941), Notorious (1946), To Catch a Thief (1955) and North By Northwest (1959). The film was another female-centered and psychological narrative in which various mysterious men terrorize a young widow (played by Audrey Hepburn), and it also featured a prestigious Hollywood director, who was known for his glossy Hollywood musicals, Stanley Donan. These various features led reviewers to conclude that the film was clearly designed to appeal to female audiences, while the marketing stressed that the film was made up from equal parts of "suspense", "comedy" and "romance", the "suspense" being largely identified with moments of psychological terrorization that elicit screams from its heroine. But these horror elements were hardly seen as inappropriate "for female audiences". On the contrary, Variety concluded that the "biggest disappointment for feminine viewers, used to the fabulous costumes Givenchy usually provides for Miss Hepburn, is the wardrobe he has provided for 'Charade.' " (Robe, 1963: 6) In contrast, the New York Times took a different tack. If Variety thought that the film had perfectly attuned its horror elements to the female audience in particular, and the family audience more generally, so that the film not only proved "excellent holiday fare" but "has it made" at the box office, the New York Times thought that the film too horrific: the film "has so many grisly touches in it and runs to violence so many times [that] the people bringing their youngsters to see the annual Nativity pageant and the Christmas stage show may blanch in horror when it comes on" (Crowther, 1963f: 40).

However, the film of 1963 that has become a horror classic is The Haunting (1963), which was based on a respected novel, Shirley Jackson's The Haunting of Hill House, and was directed by a prestigious director, Robert Wise, features that were stressed by both the marketing and the Variety review. The film was even made in the period between Wise's two major musicals, West Side Story (1961) and The Sound of Music (1965). However, while the director was, by the 1960 s, one who specialized in prestige productions, he also had other associations. Not only had he worked with Welles in the 1940s, but he had then moved on to work with Lewton, for whom Wise had directed his first film, Curse of the Cat People (1944), the film that had been central to the transformation of Lewton's reputation (Jancovich, 2012a). The Haunting of Hill House was yet another female-centered horror story and one in which its ghostly happenings were given a psychological treatment. As a result, the New York Times claimed that its central character, Eleanor, gives "alarming evidence of going understandably mad", but while the review acknowledged that the film provides "clear intimations" that her psychological state might "explain why she has hallucinations, hears noise and all that sort of thing", it objected that this doesn't explain why other characters "also hear them" (Crowther, 1963e: 23).

If the film did not feature big name stars, it actors were of high cultural respectability and marketing for the film referred them as "top talent in the world of entertainment". For example, Julie Harris was known from the Broadway stage and had appeared in prestigious Hollywood films, such as the Elia Kazan melodrama East of Eden (1955). Similarly, Clare Bloom was an English actress who achieved considerable acclaim in films such as Chaplin's Limelight (1952) and Look Back in Anger (1959). Alternatively, Russ Tamblyn was a familiar figure from prestigious family entertainments such as Seven Brides for Seven Brothers (1954), Tom Thumb (1958), West Side Story and The Wonderful World of the Brothers Grimm (1962), even if he lacked the artistic cachet of Harris and Bloom.

If The Haunting was not a glossy colour film, its black and white photography was highly regarded by the critics and the film made much of its impressive sets, sets that signified opulence and glamour but also the dangers of decadence, a feature that was also strongly associated with the dramas built around veteran female stars, more of which followed in 1964. For example, Robert Aldrich's Hush ... Hush, Sweet Charlotte (1964, the directors follow up to What Ever Happened to Baby Jane?) featured Bette Davis alongside Olivia De Havilland, Joseph Cotton, Agnes Morehead and Mary Astor; and marketing for the film boasted that it featured the winners of five academy awards. If Cotton was a male star with strong associations with the prestige horror films of the 1940s (Jancovich, 2015), De Havilland was not only the star of a number of important contribution to this cycle, Dark Mirror (1946), The Snake Pit and The Heiress (1949) but she was also the sister of one of the cycle's key female stars, Joan Fontaine, the star of Rebecca, Suspicion and Jane Eyre (1944).

The New York Times also made mention of the glamourous setting, "an old porticoed plantation mansion set off in the Louisiana fields", even if, despite its Old South glamour, this setting was also a "looneybin household". Once again, then, the film was a psychological story of "oncoming insanity" and one with strong associations with the post-Diaboliques horror film. Variety therefore claimed that the film was both the "season's 
most hair-raising filmic event" and a "handsome follow up to Robert Aldrich's 'What Ever Happened to Baby Jane?' with the same type of grosses indicated" (Whit, 1964: 6). In contrast, the New York Times attacked the film as "crudely gimmicked horror" (a comment that seemed to ridicule it through an association with the low budget efforts of William Castle, a maker of horror films who was known for his gimmicks) and one in which the director does his "grim best to generate shock", which clearly presents the film as contrived, a suggestion that it made explicit elsewhere: "So carefully carpentered and coldly calculated is the tale of murder, mayhem and deceit ... that it soon appears grossly contrived, purposely sadistic and brutally sickening." (Crowther, 1965b: 36)

De Havilland also appeared in Lady in a Cage (1964), in which she played a wealthy woman who becomes trapped in a lift that is one of the luxuries that adorn her "elegant" home (Weiler, 1964: 27), a predicament that makes her victim to a process of psychological terrorization by vicious youth. If one trailer featured De Havilland directly addressing the audience and claiming that the film was a serious social statement about sections of society "so degraded that they are worse than animals", and that the film was only for "adult, responsible" viewers who will appreciate its "terrifying theme that affects us all", Variety took exception to the film, which it described as an "unappealing shock melodrama" that offered such a "distorted distastefully sordid view of life" that it was ultimately "a noxious and repulsive film" (Tube, 1964c: 15). The New York Times went even further and described the film as "a monster" (Weiler, 1964: 27). It acknowledged that "shock is a sordid screen staple" but differentiated this film from other shock dramas because of its depiction of its characters, "horrifying types who tease, destroy, rob, torture and kill" but without any sense of motivation.

The year also saw the release of another lavish vehicle for Davis, Dead Ringer (1964), which not only placed its horrors within "a swanky array of sets [and] costumes" but was directed by Paul Henreid, Davis's co-star from her 1940s psychological classic, Now, Voyager ([1942], a role that is clearly referenced by the New York Times' description of Henreid as Davis' 'most dependable cigarette lighter" [Archer, 164: 22]) and also the star of various other classics of the 1940s, particularly Casablanca (1942). If the marketing promised "shock upon shock", Variety was rather more cautious and warned that "aggressive salesmanship" would be needed for this "old fashioned suspense melodrama about homicidal twin sisters" (both played by Davis), but was ultimately for the "less discerning, less selective moviegoer" (Tube, 1964a: 6).

Interestingly, the New York Times was more positive this time. If Variety had noted that, when it came to playing twin sisters, Davis had already done "it before, 18 years ago in 'A Stolen Life" " (Tube, 1964a: 6), it was precisely this association with the past that the New York Times seemed to relish. Unlike the Aldrich films, Dead Ringer's reference to the past was seen as a loving recreation not a grotesque caricature. As a result, while the New York Times conceded that Dead Ringer was an "uncommonly silly film", it also claimed that Davis "galvanizes" it and that Warners have lavished on her "all the extra accouterments the studio used to supply in her dramatic heyday." (Archer, 1964a, b: 22) Furthermore, Davis "does not let them down" and, for all its improbabilities, the film was seen as "great fun to watch", if only as "sheer cinematic personality on the rampage".

\section{Realism, reason and restraint}

By 1964 , then, the horror film was not only attracting larger budgets but key filmmakers were being drawn to the genre. For example, Séance on a Wet Afternoon (1964) was another British contribution that was heavily sold as a production from the "team who brought you Whistle Down the Wind, The Angry Silence and The L Shaped Room" and as one that featured an "award winning" Hollywood star, Kim Stanley. Even Richard Attenborough was claimed to have added "another triumph to his outstanding career" through his involvement in the production. The film was therefore presented as being both a serious artistic effort and as "Alfred Hitchcock Plus", a presentation that was not challenged by reviewers. On the contrary, the film was very well received and Variety stressed that it was a "macabre" and "chilly pic", in which the "seances have a fascinating, forbidding eeriness", but which was also distinguished by an "exciting realism". The film was therefore claimed to be a "remarkable picture" that was also distinguished by the quality of its performances, with special mention being made of Richard Attenborough, for whom the film was seen as a breakthrough that established him "as a character actor after longish years in younger parts." (Robe.,1964: 6) Similarly, the New York Times saw it as a distinctive film largely because of its unexpected emotional impact. It was therefore a "dandy thriller with a heart tug" that may have been "gruesome", and yet another "psychological study" that featured "an insidiously diabolic creature", but which was also "free of any exploitation taint" (Crowther, 1964d: 30).

By contrast, Night Must Fall (1964) was condemned for its lack of realism, despite bringing together the star and director of Saturday Night and Sunday Morning (1960), Albert Finney and Karel Reisz. The marketing campaign also played up Finney's recent hit, Tom Jones (1963), and referred to him as the "newest screen sensation" but it claimed that his latest role was a "fascinating and frightening portrayal". Night Must Fall was therefore clearly marketed as a psychological horror film, even if it was supposedly distinguished through its associations with the British "new wave", dual aspects that are captured by the claim that it was "filled with terror as real as life". Variety also identified Night Must Fall as psychological horror-Finney's character was a "madman"-but, although it was "fascinating to watch his dispositions shift with maniacal rootlessness", and although the film was "artfully composed and skillfully photographed", the review warned exhibitors that it would require "selling ingenuity" if they were to realize its "b.o. possibilities" (Tube, 1964b: 6). One problem was that Night Must Fall was seen as "flashy and sensationalist" and that it tended to "bully the imagination rather than just tease it". But Variety also claimed that it lacked any sense of "mystery", and that it was no more than a "spotty remake of a thriller from the thirties", a play that was not only implicitly old fashioned but had already been adapted into a "1937 shock suspense thriller".

The New York Times also saw the film's status as an adaptation in less than positive terms. The original play was again seen as old fashioned-a "30-year-old Emlyn Williams play" (Crowther, 1964c: 28)-but Night Must Fall was largely condemned for being "contrived for melodramatic effect more than for psychological logic". In other words, despite a performance by Finney, "the sheer virtuosity" of which "causes one to squirm", the film was claimed to have "avoided" the key "question in any psychological drama"-why its "psychopathic murderer" behaves as he does?so that it was "clearly short on motivation". The film may have been associated with the British "new wave" but it crucially lacked the "realism" that distinguished Séance on a Wet Afternoon, a realism that, for the New York Times, required a sense of reason and motivation for its characters' actions.

Dr Strangelove (1964) can also be understood in this context. It not only featured elements of the dark political thrillers such as The Manchurian Candidate, and of the end of the world 
narratives of 1950s horror films (and others such as On the Beach), it even made explicit reference to the horror film through the presence of Peter Sellers' mad scientist, Dr Strangelove; Sterling Hayden's demented general, Jack D Ripper; and Slim Pickens' pilot, Major "King" Kong. The trailer also featured an vocal impersonation of Bela Lugosi that was used to announce the first title, Dr Strangelove, while a brighter voice announced the alternative title, How I Learned to Stopped Worrying and Love the Bomb. Certainly, these references to horror were also mixed up with comedy and suggestions of political seriousness, so that the horror elements may seem marginal to some. However, the tension between these different aspects of the film seem to have been central to its marketing and to reviews of the film, not only through these two titles, and the ways in which they were announced, but also through the ways in which the film divided reviewers over how to reconcile, or make sense of, these different elements. For example, Variety acknowledged that "nuclear war and comedy may be seen as being at odds", but it ultimately claimed that the film was "a funny comedy" despite its "grim theme" (Daku, 1964: 6). Conversely, the New York Times claimed that it was "quite divided" in its judgment on the film, and that this was because of a situation in which "there is so much about it that is grand, so much that is brilliant and amusing, and much that is grave and dangerous" (Crowther, 1964a: 16). The problem is not just that Dr Strangelove is "the most shatteringly sick joke I've ever come across", but that it raises a crucial question: "when virtually everybody turns up stupid or insane-or, what is worse, psychopathic-I want to know what this picture proves". In other words, it is not the "goulish humour" that is the problem for the New York Times, but rather the film's assemblage of supposedly incompatible materials. Rather than providing a realistic account of nuclear politics, the film's elements of psychological horror and black comedy were supposed to have reduced its characters to deranged grotesques. Just as the paper had condemned the camp "grotesques" of What Ever Happened to Baby Jane?, so it denounced Kubrick's film as one that demonstrated nothing but "contempt". For the New York Times, the film's absurd vision of an insane world lacked the sense of diagnostic criticism that not only offered some possibility of redemption or even hope, but also demonstrated the use of reason both of which the publication had long seen as necessary to establishment of both a moral position on the one hand, and a realistic aesthetic on the other.

By 1965, the cycle reached its peak or rather was about to undergo a process of transition in response to a broader change in strategy by the major studios, but at this point the established patterns were not only still present but even intensified. Consequently, Hammer tried to upgrade its output with The Nanny (1965), and while William Castle had already had success with low budget films featuring veteran female stars (Straight Jacket (1964), Night Walker (1964)), The Nanny was a clear attempt to compete in the prestige market. The marketing therefore heavily concentrated on Bette Davis, "star of What Ever Happened to Baby Jane? and Hush ... Hush, Sweet Charlotte" but it also heavily focused on the psychological aspects of the film: "Was Nanny to blame when this radiant young mother crumbled into a neurotic woman?" and "Is he [the young boy who opposes Nanny] terrorized or terrorizing?"

Nor did the press contradict this sense of the film. Variety declared it a "sound booking for psycho thriller addicts", although it added that the film should have broader appeal and would prove "a plus entry for most audiences" (Rich, 1965b: 6). Essentially, "a fascinating duel ... between Bette Davis and a knowing youngster", the film was praised for ensuring that nothing "teeters over the edge into hysteria" and that even Davis gives a "restrained yet compelling performance". Other indications of quality were also identified, so that the review stressed the film's status as an adaptation of a novel by the same writer as Bunny Lake is Missing (1965, see later), and also that The Nanny featured "two of Britain's outstanding young femine [sic] thesps", Jill Bennett and Wendy Craig, the latter having recently starred in The Servant, which The Nanny clearly worked to evoke in various ways. The New York Times also stressed the film's psychological aspects and claimed that its "shifting game of cat and mouse, provide the spice and real merit of the film" (Thompson, 1965: 57). Its review also praised the film as a "small scale chiller" that was the "quietest, tightest and most lifelike Davis film in a cavalcade of gory jamborees that started with "Whatever Happened to Baby Jane?"' Certainly, it was not uncritical of the film, but its quibbles were fairly small ones. For example, the film was said to be "obvious, but never dull" and it was even claimed that the film "could have been crackerjack", if only it had "held fast to the youngster's point of view" right until the end.

Alternatively, Hammer's Die, Die, My Darling (1965) featured Tallulah Bankhead as another veteran female star but it was a far more lurid affair. Certainly the marketing tried to create an association with Hush ... Hush, Sweet Charlotte through its use of a similar nursery rhyme in trailers. The film was also presented as a psychological horror story or "the most terrifying suspense thriller this side of insanity". Similarly, Variety praised the "expert thesping by Tallulah Bankhead", and claimed that it "should appeal to fright trade" while also having the potential to "take off with general audience the way other horror pix with veteran actresses have done" (Hogg, 1965: 6). However, despite these positive points, this review was much more cautious than that for The Nanny, and the New York Times was even less convinced, explicitly associating the film with Hammer's horror monster films through the claim that it had "the blood thirsty tendencies of a vampire". Even then it was not seen as very effective so that it was "hardly likely to shock, scare or surprise a moviegoer inured to daffy dowagers" (Weiler, 1965: 52).

In addition, the year saw three key films that represented the culmination of the cycle but also provided a sense of where the prestige horror films would go next. Bunny Lake is Missing, for example, was an expensive psychological thriller that was not only based on a novel but had also been adapted by respected playwright, John Mortimer and his wife. The film's marketing, however, revolved around its director, Otto Preminger, who features in trailers where he addresses the audience directly in much the same way that Hitchcock had done in trailers for Psycho and The Birds. Preminger had recently been known for a series of big budget, prestige and/or road show productions, such as Anatomy of a Murder (1959), Exodus (1960), Advice and Consent (1962) and The Cardinal (1963) but he also stressed the reputation of his stars, particularly Lawrence Olivier and Noel Coward, the former said to be "often acclaimed as the greatest living actor". 6 Even his younger male star, Keir Dullea, was claimed to be someone "who you might remember from David and Lisa", a recent and highly praised psychological drama. Carol Lynley gets less mention, although Variety presented her as the central character, given that she is said to carry "much of the film on her shoulders" (Robe, 1965: 6). She was therefore one of a small group of young female stars who would become associated with the 1960s prestige horror film (Mia Farrow, Audrey Hepburn, Lee Remick and Katherine Ross), and she would also go on to appear in a number of horror films and television projects, including The Shuttered Room (1967); an episode of Hammer's Journey to the Unknown (1968, produced by Joan Harrison, a key figure from the 1940s and the producer of Alfred Hitchcock Presents); Once you Kiss a Stranger (1969); the celebrated made-for-television horror film, The Night Stalker (1972); an episode of Night Gallery (1972); and Beware the Blob (1973). 
Variety also stressed the psychological aspects of the film, which was said to be "an entertaining, fast paced exercise in the exploration of a sick mind" and one that was implied to be female-centered with Lynley's character being "shoved into a state of near hysteria" by its events (Robe, 1965: 6). The review also made much of the director, although the film was claimed to be "Otto in Hitchcockland", a statement that suggested that this was not Preminger's natural habitat, although the review did note that the film was his "first try at suspense since 'Laura" (Robe, 1965: 6). In other words, Preminger's presence was associated with another classic of the 1940s horror film, even though the director had gone in a quite different direction from the early 1950s onwards and Bunny Lake is Missing was "no minor classic on the level of his "Laura". If Variety still regarded the film as a "worthy effort", the New York Times took exception to it and claimed that what was absent in this "grossly calculated attempt at a psychological mystery thriller is just plain common sense" (Crowther, 1965d: no page number). Its psychological story of "two kooks, ridden with fantasies from childhood" is hardly taken seriously and, despite all the talent involved, the New York Times claimed that the film was another prestige production that lacked both realism and reason.

Another key director who became involved in horror that year was William Wyler, who had a long reputation as one of the prestige directors in Hollywood and was associated with numerous prestigious productions, the most recent of which was Ben Hur (1959). Wyler had even been asked to direct the film adaptation of The Sound of Music but had turned it down to direct his contribution to the horror films of the 1960s, an adaptation of John Fowles' acclaimed first novel, The Collector, the trailer for which described Wyler as "Hollywood's most honoured director". This lavish, colour production also starred two young actors, Terence Stamp and Samantha Eggar (who won an Academy Award for the role), both of whom the trailer introduces as figures on the verge of stardom and for whom their roles in The Collector were likely to prove a breakthrough. Another study of a deranged serial killer in the making, the trailer even quotes Time magazine, which had supposedly described Stamp's character as "one of the most cunning, evil characters of modern fiction". The trailer also associated the film, and its horror, with taboo breaking realism and described the tale as one that was so "shockingly special" that it "could only be told today". Consequently, Fowles' novel was described as a "bold and breathless international best seller" that had been adapted with the "uncompromising realism [that] its story demands".

If the film was clearly identified as "a shocker", Variety saw it as one that featured "remarkably restrained performances" and a director "at his top best". Indeed, Wyler was supposed to have demonstrated "rare artistry" and to have "handled unconventional themes with tact and imagination" (Whit, 1965: 6). However, it was precisely this tact that concerned the New York Times, which referred to Norman Bates in Psycho and Stamp's character in The Collector as "sex fiends", but claimed that the latter was "weak, vacillating and obscure" by comparison with the former (Crowther, 1965a: 28). Certainly, this comment presented the film as a psychological one, a tale of "mania" and "deep complexes", but while the film was claimed to be "mystifying and fascinating at the start", it was also supposed to be no more than a "melodramatic blob" by the end. In other words, the New York Times saw a tension between the respectability that a director such as Wyler brought to the film, and the realism that the story demanded.

\section{Conclusion}

In other words, despite claims to The Collector's taboo breaking realism, the film was also associated with the glossy Hollywood respectability of Wyler, and the very tact that Variety praised led the New York Times to claim that the film was incapable of "penetrating" the "dark behaviour" of its characters so that it was no more than a "low key chiller" (Crowther, 1965a: 28). In contrast, the New York Times championed the realism of younger directors, such as Roman Polanksi, whose association with the art cinema meant that Repulsion (1965) was seen as a model for the prestige horror film. For the New York Times, then, Repulsion managed to "penetrate and expose the alien and angry impulses of the subconscious mind" in precisely the way that The Collector did not (Crowther, 1965c: 7). Consequently, while it may have been made by low budget producer, Tony Tenser, who said that it was "like ordering a Mini Cooper and winding up with a Rolls" (Rigby, 2000: 9), the film was marketed though its association with "internationally acclaimed Polish director", Roman Polanski, and it was claimed to be "a frightening film that takes the everyday world and distorts it". Again, it was a female centered narrative that took one "inside the mind of a girl driven to insanity" and it was claimed that "no other film has ever shown, with such intense reality, the terrifying journey into madness" until "the horrors from her twisted mind spill over into reality."

In this way, Repulsion was seen as having transcended its low budget origins so that it is not only a "standout psychological horror pic" but one that was made in a manner that "lifts what might have been a mere horror meller to a much higher and more satisfying plane" (Rich, 1965a: 6). It might "need a heavy sell to tap all but discerning audiences" but its "quality in the semi-arty field cannot be questioned" (Rich, 1965a: 6). Elsewhere, it was claimed to be "an absolute knockout of a movie in the psychological horror line" (Crowther, 1965c: 7) but also to be more than just a tale of "mounting horrors that moves its heroine ... from a state of mental woe into a stage of dithering madness and then to the dark extremity of murdering a brace of fellows." If it was "a detailed and gruesome account of a crumbling mind", it was nonetheless one designed to "penetrate and expose" its "maelstrom of violence and horror" so that the result was not just a prestige horror film but "one of the best films of the year".

Furthermore, Repulsion prefigured major shifts later in the decade as the major studios suffered a series of crushing losses because of their concentration of the road show productions and increasingly focused their efforts on the youth and art house audiences, a strategy that led to a change in both the themes and styles of Hollywood filmmaking but also, in the process, led to a renewed concentration on the first run markets into which it had allowed the likes of Hammer and AIP to make significant inroads a decade earlier. In a sense, then, the horror films of the late 1950s and early 1960s established many of the strategies that the major studios would adopt in the late 1960s and early 1970s, the period of the so-called Hollywood Renaissance.

\section{Notes}

1 Psycho was budgeted at around $\$ 800000$, which was less than the $\$ 3$ million that Hitchcock had spent on North By Northwest (1959), but was still four times the budget for a film such as William Castle's The House on Haunted Hill (1959) and almost ten times the budget of Castle's Macabre (1958).

2 Indeed, Hammer also demonstrates the peculiar transatlantic nature of this period in horror, with British studios such as Hammer being largely defined by their strategy for their US first run market, while many of the prestige horror films made by the major studios were either filmed in the United Kingdom or sought to evoke a sense of Britishness in other ways: Midnight Lace (1960), Village of the Damned (1960), The Haunting (1963), Bunny Lake is Missing (1965) and The Collector (1965).

3 Of course, Hammer was not alone in this strategy and, as Heffernan has shown, following the success of the British studio, American International Pictures (AIP) dramatically increased the budget for some of its films, and began to make productions, such as Roger Corman's The Fall of the House of Usher (1960), that also sought to compete within the first run market. Furthermore, these productions not only featured bigger budgets, and were often based on respected source material, but they also followed Hammer's lead in another way and drew upon the art cinema. If 
Hammer sought to align its films with the art cinema's shocking realism, The Masque of the Red Death (1964) and other Corman films drew on the imagery and symbolism of art house hits such as Ingmar Bergman's The Seventh Seal (1957).

4 The only diversion from this practice is in the rare case, such as On the Beach (1959), where generic associations are significant because of their absence.

5 Hitchcock's status is hardly in question, but Michael Powell's reputation may be less familiar. However, in the 1940s and 1950s, his status was considerable with films such as A Matter of Life and Death (1946), Black Narcissus (1947) and The Red Shoes (1948) being seen by many US critics as key contributions to the art of cinema, even if these films that were largely restricted to an art house audience. While his 1950s films may not have attained quite the same levels of praise, they were still prestige productions from a name director, and Peeping Tom's association with low budget filmmaking is largely due to Pirie's claim that it was part of a 'Sadian' trilogy that also included Horrors of the Black Museum (1959) and Circus of Horrors (1960), although neither of these films were directed by Powell and each film was made by a different production company, even if they shared a distributor.Furthermore, if Peeping Tom's estimated budget of $£ 135,000$ does seem low when compared to both Hitchcock's Psycho (see footnote 1), it was still considerably more than that of a film such as The House on Haunted Hill, particularly when you take into account the exchange rate and that production in the UK was far cheaper than in the US at this time. It therefore looks considerably different when placed alongside other British films of the period, so that while certainly no Sink the Bismark (1960), which was budgeted at 1.3 million, it still had a bigger budget than a series of modest, rather than low, budget British productions from 1960: The Angry Silence, $£ 98,000$; Hell is a City, £115,000; and Saturday Night and Sunday Morning, $£ 100,000$. Even a prestige issue picture such as Victim (1961), which starred Dirk Bogarde, was only budgeted a little higher at $£ 154,000$. Finally, the size of the budget may also have been a consequence of the film's failure to attract a major star, with both Dirk Bogarde (Victim) and Lawrence Harvey (Room at the Top, 1959) being unsuccessfully pursued by producer Nat Cohen for the central role. Indeed, the pursuit of both Bogarde and Harvey demonstrated that the filmmakers were keen to distinguish the film from low budget filmmaking in much the same way that Hitchcock had done with his use of Psycho's stars.

6 Olivier also carried strong associations with the 1940s horror film, having stared in Wuthering Heights (1939) and Rebecca (1940) but had also gained considerable kudos for his Gothic reworking of Hamlet in 1948, which even won the Oscar for best film (Jancovich, 2012b)

\section{References}

Alpert H and Beaumont C (1959) The Horror of it All. Playboy, March: 68-69, 74, 76, 86-88.

Altman R (1999) Film/Genre. British Film Institute: London.

Archer E (1960) Bluebeard's Ten Honeymoons Opens. New York Times 8 November: 32.

Archer E (1964a) Dead Ringer. New York Times 20 February: 22.

Archer E (1964b) Marnie. New York Times 23 July: 19.

Auby. (1962) The Manchurian Candidate. Variety 17 October: 6.

Beaver FE (1974) Bosley Crowther: Social Critic of Film, 1940-1967. New York: Arno Press.

Crowther B (1959a) Screen: A Court Classic (Review of Anatomy of a Murder). New York Times 3 July: 10.

Crowther B (1959b) Journey to the Centre of the Earth: Verne Fable Opens at Paramount. New York Times 17 December: 51.

Crowther B (1959c) Screen: On the Beach. New York Times 18 December: 34.

Crowther B (1960a) Psycho. New York Times 17 June: 37.

Crowther B (1960b) Screen: Glimpses of Life in 800,000 A.D.: The Time Machine Opens at Warner Version of H. G. Welles Thriller Is in Color. New York Times 18 August: 19.

Crowther B (1960c) Screen: 'Midnight Lace,' A Mystery Arrives: Color Melodrama is at the Music Hall, Doris Day Co-Starred with Rex Harrison. New York Times 14 October: 27.

Crowther B (1961a) The Screen: 'Sanctuary': Adaptation of William Faulkner Novels has Premiere. New York Times 22 February: 31.

Crowther B (1961b) Screen: 'The Innocents': Film From James Tale is at Two Theatres. New York Times 26 December: 15.

Crowther B (1962a) Screen: Sirens Wailing: 'Experiment in Terror' Opens at Criterion. New York Times 14 April: 14.

Crowther B (1962b) Screen: Pitiless Shocker: Mitchum Stalks Peck in 'Cape Fear'. New York Times 16 April: 35.

Crowther B (1962c) Screen: 'The Manchurian Candidate': Laurence Harvey and Frank Sinatra Star Brainwashing is Theme of New Film. New York Times 25 October: 48.

Crowther B (1962d) Screen: Bette Davis and Joan Crawford: They Portray Sisters in Melodrama Whatever Happened to Baby Jane Opens. New York Times 7 November: 48 .

Crowther B (1963a) Screen: 'To Kill a Mockingbird': One Adult Omission in a Fine Film 2 Superb Discoveries Add to Delight. New York Times 15 February: 10.

Crowther B (1963b) The Screen: 'The Birds': Hitchcock's Feathered Fiends are Chilling. New York Times 1 April: 5.
Crowther B (1963c) The List of Adrian Messenger. New York Times 30 May: 20.

Crowther B (1963d) Screen: Agitating Fable of Wild Boys: Savagery Is Depicted in 'Lord of the Flies'. New York Times 20 August: 37.

Crowther B (1963e) The Screen: An Old-Fashioned Chiller: Julie Harris and Claire Bloom in 'Haunting'. New York Times 19 September: 23.

Crowther B (1963f) Screen: Audrey Hepburn and Grant in 'Charade': ComedyMelodrama Is at the Music Hall Production Abounds in Ghoulish Humor. New York Times 6 December: 40.

Crowther B (1964a) Dr Strangelove: Or How I Learned to Stop Worrying and Love the Bomb. New York Times 31 January: 16.

Crowther B (1964b) The Servant. New York Times 17 March: 30.

Crowther B (1964c) Robert Montgomery's Role Is Re-Created: Emlyn Williams Drama in New Adaptation. New York Times 19 March: 28.

Crowther B (1964d) Seance on a Wet Afternoon. New York Times 6 November: 30.

Crowther B (1965a) Terence Stamp Stars in "The Collector". New York Times 18 June: 28.

Crowther B (1965b) New Movie at Capitol Echoes 'Baby Jane' (review of Hush, Hush Sweet Charlotte). New York Times 4 March: 36.

Crowther B (1965c) Movie on Insanity By Pole Opens at N.Y. Theatre (review of Repulsion). New York Times, 4 October: 7.

Crowther B (1965d) Bunny Lake is Missing. New York Times unpublished due to strike.

Daku. (1964) Dr Strangelove: Or How I Learned to Stop Worrying and Love the Bomb. Variety 22 January: 6.

Dale. (1962) Experiment in Terror. Variety 21 March: 8.

Gene. (1960) Psycho. Variety 22 June: 6.

Gomery D (1986) The Hollywood Studio System. British Film Institute: London.

Gomery D (1992) Shared Pleasures: A History of Movie Presentation in America. British Film Institute: London.

Hardy P (1985) The Aurum Film Encyclopedia: Horror. Aurum: London.

Hawkins J (2002) See it from the beginning: Hitchcock's reconstruction of film history In: Gottlieb S and Brookhouse C (eds) Framing Hitchcock: Selected Essays from the Hitchcock Annual. Wayne State University Press: Detroit, MI, pp 373-386.

Heffernan K (2004) Ghouls, Gimmicks and Gold: Horror Films and the American Movie Business, 1953-1968. Duke University Press: Durham, NC.

Hift. (1959) Compulsion. Variety 4 February: 6.

Hogg. (1965) Die, Die, My Darling. Variety 28 April: 6.

Holl. (1959) Journey to the Centre of the Earth. Variety 9 December: 6.

Jancovich M (1996) Rational Fears: American Horror in the 1950s. Manchester University Press: Manchester.

Jancovich M (2007) Crack-Up: Psychological Realism, Generic Transformation and the Decline of the Paranoid Woman's Film. Irish Journal of Gothic and Horror Studies, November: https://irishgothichorror.files.wordpress.com/2016/ 04/ijghsissue3.pdf.

Jancovich M (2009) Shadows and Bogeymen: Horror, stylization and the critical reception of Orson Welles during the 1940s. Participations; 6 (1): 1-27.

Jancovich M (2010) Two ways of looking: The critical reception of 1940s horror. Cinema Journal; 49 (3): 45-66.

Jancovich M (2011) “The English Master of Movie Melodrama": Hitchcock, Horror and the Women's Film. Film International, 9: 51-67.

Jancovich M (2012a) Relocating Lewton: Cultural distinctions and generic negotiations in the critical reception of the val lewton horror films. Journal of Film and Video; 64 (3): 21-37.

Jancovich M (2012b) "Psychological thriller": British cinema, horror and the cultural contexts of dead of night during the 1940s In: Picart CJS and Browning JE (eds) Speaking of Monsters: A Teratological Anthology. Palgrave Macmillan: London, pp 39-53.

Jancovich M (2013) 'Bluebeard's Wives': Horror, quality and the paranoid woman's film in the 1940s. Irish Journal of Gothic and Horror Studies; 12, 20-43.

Jancovich M (2014) Horror in the 1940s In: Benshoff $\mathrm{H}$ (ed) A Companion to the Horror Film. Wiley-Blackwell: Malden, MA, pp 237-254.

Jancovich M (2015) Victims and villains: Psychological themes, male stars and horror films in the 1940s In: Geraghty L (ed) Popular Media Cultures. Palgrave Macmillan: London, pp 91-109.

Jancovich M (2016) Ingrid Bergman In: McCarthy E and Murphy BM (eds) Lost Souls of Horror and the Gothic. McFarland: Jefferson, TX, pp 34-37.

Kapsis RE (1992) Hitchcock: The Making of a Reputation. University of Chicago Press: Chicago, IL.

Klinger B (1994) Melodrama and Meaning: History, Culture and the Films of Douglas Sirk. Indiana University Press: Bloomington, IL.

Lev P (2003) The Fifties: Transforming the Screen, 1950-1959. University of California Press: Berkeley, CA.

Marwick A (1992) British Society Since 1945. Penguin: Harmondsworth, UK.

Monaco P (2003) The Sixties, 1960-1969. University of California Press: Berkeley, CA

Mosk. (1963) Lord of the Flies. Variety 22 May: 6.

Myro. (1963) The Servant. Variety 11 September: 22. 
Pitt. (1962) Cape Fear. Variety 7 March: 8.

Powe. (1959) On the Beach. Variety 2 December: 6.

Rich. (1960a) Bluebeard's Ten Honeymoons. Variety 30 March: 22.

Rich. (1960b) Peeping Tom. Variety 20 April: 8.

Rich. (1960c) Village of the Damned. Variety 29 June: 8.

Rich. (1961) The Innocents. Variety 6 December: 6.

Rich. (1965a) Repulsion. Variety 16 June: 6.

Rich. (1965b) The Nanny. Variety 13 October: 6.

Rigby J (2000) English Gothic: A Century of Horror Cinema. Reynolds and Hearn: London.

Robe. (1962) WhatEver happened to Baby Jane? Variety 31 October: 6.

Robe. (1963) Charade. Variety 25 September: 6.

Robe. (1965) Bunny Lake is Missing. Variety 6 October: 6.

Sontag S (1964) Notes on "Camp". Partisan Review, Fall: 515-30.

Suarez JA (1996) Bike Boys, Drag Queens, and Superstars: Avant-Garde, Mass Culture, and Gay Identities in the 1960s Underground Cinema. Indiana University Press: Bloomington, IL.

Taylor G (1999) Artists in the Audience: Cults, Camp and American Film Criticism. Princeton University Press: Princeton, NJ.

Thompson H (1960) Village of the Dammed. New York Times 8 December: 43.

Thompson H (1965) Bette Davis as 'The Nanny'. New York Times 4 November: 57.

Tube. (1960a) The Lost World. Variety 6 July: 22.

Tube. (1960b) The Time Machine. Variety 20 July: 6

Tube. (1960c) Midnight Lace. Variety 19 October: 6.

Tube. (1960d) Sanctuary. Variety 22 February: 6.

Tube. (1960e) Voyage to the Bottom of the Sea. Variety 28 June: 6.

Tube. (1962) To Kill a Mockingbird. Variety 12 December 12: 6.

Tube. (1963a) The Birds. Variety 27 March: 6.

Tube. (1963b) The List of Adrian Messenger. Variety 29 May: 6.

Tube. (1963c) The Haunting. Variety 21 August: 6.

Tube. (1964a) Dead Ringer. Variety 29 January: 6.

Tube. (1964b) Night Must Fall. Variety 18 March: 6.

Tube. (1964c) Lady in a Cage. Variety 3 June: 15.

Tudor A (1989) Monsters and Mad Scientists: A Cultural History of the Horror Movie. Blackwells: Oxford.

Weiler AH (1959) The Screen: Compulsion. New York Times 2 April: 26.
Weiler AH (1960) Screen: 'The Lost World': Remake of Doyle Story Opens at Warner. New York Times 14 July: 23.

Weiler AH (1964) Aimless Brutality (Review of Lady in a Cage). New York Times 11 June: 27.

Weiler AH (1965) Tallulah Bankhead Stars in British-Made 'Die! Die! My Darling!' New York Times 20 May: 52.

Whit. (1964) Hush ... Hush, Sweet Charlotte. Variety 23 December: 6.

Whit. (1965) The Collector. Variety 26 May: 6.

Wood R (1986) Hollywood from Vietnam to Reagan. Columbia University Press: New York.

Worland R (2014) The Gothic Revival, (1957-1974) In: Benshoff H (ed) A Companion to the Horror Film; Malden, MAWiley-Blackwell, 273-291.

\section{Data Availability}

Data sharing is not applicable to this article as no datasets were analysed or generated.

\section{Additional Information}

Competing interests: The author declares that there are no competing interests.

Reprints and permission information is available at http://www.palgrave-journals.com/ pal/authors/rights_and_permissions.html

How to cite this article: Jancovich M (2017) Beyond Hammer: the first run market and the prestige horror film in the early 1960s. Palgrave Communications. 3:17028 doi 10.1057/palcomms.2017.28

Publisher's note: Springer Nature remains neutral with regard to jurisdictional claims in published maps and institutional affiliations.

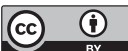

This work is licensed under a Creative Commons Attribution 4.0 International License. The images or other third party material in this article are included in the article's Creative Commons license, unless indicated otherwise in the credit line; if the material is not included under the Creative Commons license, users will need to obtain permission from the license holder to reproduce the material. To view a copy of this license, visit http://creativecommons.org/licenses/by/4.0/ 